\title{
Metaphor as a cultural vehicle of historical memory between the Dema and Nyungwe of the Zambezi valley - Mozambique
}

\begin{abstract}
The present work aims to approach the culture between the Dema and Nyungwe peoples of Mozambique in their relations with the colonial power in which the metaphor proved to be a fundamental language and vehicle for its preservation. This power was so marked and invasive that it came to deny culture, history, religion, literature and the different ways of being non-Western. Orality, as a method of transmitting knowledge, remains among the African peoples one of the main sources of knowledge-power.
\end{abstract}

Keywords: culture, metaphor, azungu
Volume 6 Issue I - 202 I

\author{
Antonio Alone Maia \\ Department Anthropology, Faculty of Arts and Social Sciences, \\ Rovuma University, Mozambique
}

Correspondence: Prof. Dr. Antonio Alone Maia, Department Anthropology, Faculty of Arts and Social Sciences, Rovuma University, Mozambique, Email Alonemaia I3@gmail.com

Received: May 20, 2021 | Published: June 28, 2021

\section{Geographic location of Mozambique}

Mozambique is located on the east African coast, bathed by the Indian Ocean, enjoys a privileged geographical location, bordering six countries: Tanzania, Malawi, Zambia, Zimbabwe, South Africa and Swaziland. In geopolitics, the country is a gateway to these southern regions of the continent.

The country has hydrographic basins and the main ones are: from north to south, the Rovuma River, Lúrio, Ligonha, Zambeze, Púnguè, Save, Limpopo and Incomati. Throughout history these rivers have been of paramount importance as routes of communication between the coast and the interior. In this sense, the Zambezi River stands out, as we will see later on.

Recently, the names of some of these rivers have been transformed into university names, as follows: the Zambezi University UniZambeze, Rovuma University - UniRovuma; Lurio University UniLurio; Save University - UniSave; Pungue University - UniPungue.

The Zambezi River enters Mozambican territory, coming from Zimbabwe, through the town of Zumbo, in the northwest of the province of Tete, crossing three different territorial areas: the High and Mountainous Lands up to Cahora-Bassa, the Plateau Lands up to the Lupata Strait and, finally, the Alluvial Lowlands, from here to the sea (Indian Ocean). The Zambezi has been navigable to Cahora-Bassa (ROSÁRIO, 1989: 25).

Throughout history, the Zambezi River has been a great channel of communication with the interior regions of Africa. This strategic position served for people from the most diverse parts of the world to come in contact with the peoples of the East African coast for different purposes: trade, slavery, territorial domination and exploitation of immense wealth, such as gold and ivory (M'BOKOLO,2009:253).

\section{The dema and the nyungwe}

The Nyungwe people are one of the people of Mozambique who live in the province of Tete. We want to draw attention here against the danger of simplification and homogenization, as there is great cultural diversity in the region. In the same geographical area called Tete province, other ethnic groups also live in addition to the Nyungwe, who are from the central part of the province. To the north are the Angoni descendants of the nguni who came from Kwazulu Natal on the Chaka Zulu trail. They live in the Angonia region and speak Nyanja and Cewa; in the center are the Nyungwe or Anyungwe that we are talking about, as well as the Dema, however, these are in the high and mountainous regions, in the district of Songo, better known as Cahora Bassa because of the Hydro-electric Dam built here. South of the Zambezi River are the Cena or Macena that span the Mutarara region below.

However, there are other collective identities known by the names of the villages or districts where they live. This is the case of the Amalala of the region called Marara, famous for having an ancient Catholic mission there; Wa ku Chitima because they are inhabitants of Chitima, a region where there is also an old Catholic mission; wa $k u$ Dzuntsa because they are from Dzuntsa. After the regions from Marara to Zumbo, all groups are Tauaras.

There are the Dema or Madema or Adema, who are the natives of Songo Village, where there is also an old Catholic mission. Songo is a region where the largest hydroelectric dam in the country is built, the Cahora-Bassa hydroelectric dam. Wa ku Maroeira because they are from Maroeira; wa ku cirodzi because they are from Cirodzi; wa ku Magoe, because they are from Magoe. Wa ku Cipera because they are from Cipera. The same applies to the other provinces.

Therefore, it is necessary to be cautious with homogenization, since it can make other identities invisible, thus endangering the multiculturalism that is experienced in the country and that is its trademark. This denomination of people by their place of origin is very common, although they are part of a large ethnic group of belonging, but the bond and identification with the place always prevails. In social relations it is very common for people to treat themselves by the name of the place of origin rather than by invoking the name of the ethnic group. Each Mozambican, when asked: Where are you from? In the answer, he does not make a fuss, but he is able to integrate the three identities, the local, the provincial and the national. The aforementioned groups share the same provincial identity because they are all from Tete, the same national identity because they are Mozambicans and at the same time each presents himself with his local identity, from the lucus of his ancestors. 
These three harmonized identities contribute to the self-affirmation of the Mozambican person in a trip belonging: local, provincial and national. However, these identities have undergone an irrefutable world historical transformation process, before which Hall questions: "What is so powerfully displacing national cultural identities, now, at the end of the 20th century? The answer is: a complex of processes and forces of change, synthesized under the term of globalization" (HALL, 2001:67).

Some prophets have already pointed to the failure of globalization. Ki-Zerbo says that, we have reached a great moment in human history. When globalization fails, and is on the way to failure, because it produced not only poverty, but impoverishment, it will be the time for the right strategic options for humanity as a whole. When it is proven that capitalism also does not have a decisive, definitive answer to give to a correct human history, perhaps the conditions are in place to finally discover a specific solution: to install a new decoration, invent a new scenario and make a new choice of actors for a new play, more worthy of the human being (KI-ZERBO, 2009: 19-20).

According to Castro, "the historical transformations are in continuity with the structural transformations, the societies in " contact " are necessarily transformations of each other" (VIVEIROS DE CASTRO, 2011). Beginning in the 16th century, with the invasions coming from abroad, the race for Africa never changed and did not stop. The discoveries of Africa in southern Sahara and Latin America culminated in trafficking involving the forced displacement of Africans.

No human collectivity has been more systematically disqualified than in Africa, with millions of people enslaved (KI-ZERBO, 2009: 23-24).

That is why, when we talk about Mozambican identity, resuming the colonial situation is essential, as it left indelible marks in Mozambique, according to Omar: "The Mozambican identity crosses identities constructed in the midst of the institutionalization of the colonial state, the war of liberation and the formation of the country as an independent nation-state" (THOMAZ. Apud CABAÇO, 2009: 15-16).

It is in this sense that Cabaço understands the identity policies promoted by colonialism which aimed to legitimize the domination exercised, destabilizing central aspects of the organization of traditional power, which stimulated cultural responses that reinforced identities of resistance through the appropriation of subsidies from the 'modernity' of colonialism in the very heritage of knowledge and experiences (CABAÇO, 2009: 20). Our focus, therefore, is on these identities of resistance, with greater emphasis on metaphor as a means of subtle resistance against the alius (COMBA, 2002: 193).

\section{Culture}

In view of the colonial situation, we ask ourselves what was the "other" for the colonial system that prevailed in Mozambique until the eve of the independence achieved in 1975? To what extent was cultural diversity taken into account in this colonial situation? "The diversity of cultures is in fact in the present, and also in the past, much greater and richer than everything we are destined to know about it" (LEVÍ-STRAUSS, 2000: 14).

Does the local culture, including local medical knowledge, forms of religiosity such as the cult of ancestors widely fought under the regime, these local cultures destroyed, is there anything left? The questions lead to another very important question: what conceptions of culture were in force until then?

In his work "Race and history" Levis-Strauss defines man as being "The one that I am, the one that lives with me and like me and, however, is also the other, no matter how different I may be (...). The 'also', it has a sense and reason for being, because it is ware at the same time of the difference it supposes and the similarity it affirms between men"(LEVÍ-STRAUSS, 2000: 71).

For the author, the discovery of otherness is also the discovery of a relationship, not a barrier. It can confuse perspectives, but it broadens horizons. Some "primitives" reserved only the name of men for themselves and refused it to others, this has little meaning (LEVÍSTRAUSS, 2000: 71). The other is always, for the author, another human. The other is the one that I know that I have to understand in a relationship that I also know reciprocal of reciprocity, which, of course, does not mean that it will be achieved. Alterity does not prevent understanding, quite the contrary. For Levis-Strauss, this is the starting point of otherness and it is also here that misunderstandings begin (LEVÍ-STRAUSS, 2000: 72).

The author still works on the term understand: what is its meaning? For him, to understand would be to assimilate, to make similar to what first appears as different, that is, it would be to transform difference into identity (LEVÍ-STRAUSS, 2000: 14). It is in this sense that Wayway states that the Difference, otherness, diversity challenge western hegemony and postulates that coexistence relationships must be discussed" (RUFIN, 2006: 109).

The other calls for responsibility. Responsibility without concern for reciprocity, says Levinas. "I have to answer for someone else without taking on his responsibility towards me" (LEVINAS, 2002: 16). "Let the other be someone else; that the exit from oneself must be the approximation of the next; that transcendence must be proximity; that proximity must be responsibility for the other " (LEVINAS,2002:32).

Junqueira understands that understanding the other is a task of anthropology (JUNQUEIRA, 2008:7). Differences are secondary in the face of otherness. The other is also a human, not in, but despite its difference. Thus, for Levi-Strauss, we are led to a curious paradox: humanity is placed outside and above cultures.

How do we identify that a person is becoming an adult? In Junqueira's conception, one of the signs that the person is becoming an adult is the development of the ability to pay more attention to the behavior of others, trying to decipher and understand it. It is an attitude that replaces the childish desire to command the world to his own taste and that opens space for new experiences (JUNQUEIRA, 2008: 7).

In this sense, the fantasy of omnipotence takes its first hit on the impact of social interaction, which sets limits on individual action. Opening to the outside is one of the first steps towards knowledge of the other, of the world and also of self-limitations (JUNQUEIRA, 2008: 7).

Therefore, it is possible to identify the maturity of a society, as well as the members of a given social institution, by the quality that it and they develop to understand and relate to others. Instead of making your own habits and values act as a hindrance to knowledge, it embarks on the fascinating adventure of trying to understand the different, the other, not as an obstacle or as an enemy, but only as different. It is in this perspective that the work of anthropology becomes a systematic 
effort to decipher different ways and lifestyles, significantly adopted by other peoples (JUNQUEIRA, 2008: 8-9).

It is worth recalling here the Levinas hypothesis, according to which, "The absolute otherness of the other cannot be found in the subject who is definitely himself. This otherness only comes to me from someone else, who is not me" (LEVINAS, 1998: 111-113).

In Laraia's view, every cultural system has its own logic and is nothing more than a primary act of ethnocentrism trying to transfer logic from one system to another. The author calls it unfortunate, the common tendency to consider only one's system itself as logical and to attribute to others a high degree of irrationalism. The coherence of a cultural habit can only be analyzed from the system to which it belongs (LARAIA,2008:87)

The human quality of giving meaning is called the ability to symbolize, to represent the reality whose product is the symbol. Thus, everything that is socially created can be understood as a symbol (JUNQUEIRA, 2008: 12). The set of symbols of a society is called culture (JUNQUEIRA, 2008: 14). Gaudium et Spes defines culture as being all the things through which man refines and develops the multiple capacities of his spirit and body; it strives to dominate, through study and work, the world itself; makes human life more human, with the progress of customs and institutions, either in the family or in the civil community; and finally, over time, expresses, communicates to others and keeps in his works, so that their great spiritual experiences and aspirations may be of benefit to many and even to the whole of community(GAUDIUM ET SPES, $\mathrm{n}^{\circ} 53$ ).

In number 109 of Verbum Domini, Benedict XVI, he stresses the idea that "Man always lives according to a culture that is his own and in turn creates a bond between men, which is also their own, determining the inter-human and social character of human existence" (Benedict XVI. Post-syndol Apostolic Exhortation: Verbum Domini. $\left.\mathrm{N}^{\circ} 109,2010\right)$.

In the colonial period, there is a conception of culture that denies these ties and all the capacity to symbolize the other non-European, that is, culture loaded with expansion and colonial domination. Culture linked to the notion of civilization, that is, the European's gaze on the other who fell under his domain (HASTINGS,1974:14).

The most important was the "assimilation" and westernization of Africans. The latter were not allowed to be themselves, with their language and culture. Psychological identification with Portugal, the metropolis, was the most important. This was a policy of pure cultural genocide, according to Hastings (HASTINGS,1974:85).

Faced with the context of Africa's decolonization, Geertz repudiates the current concept of culture and formulates a new semiotic concept of culture inspired by Max Weber's sociological theory. In Weber, Geertz takes the idea that "man is an animal tied to webs of meanings that he himself wove" (GEERTZ, 2008: 4). Thus, says the author, "I take culture as being these webs and their analysis; not as an experimental science in search of laws, but as an interpretive science, in search of meanings" (GEERTZ, 2008: 4).

For him, to do ethnography in the dense description is to reveal the webs, that is, several webs of constructed meanings. What the ethnographer faces is a multiplicity of complex conceptual structures, many of them overlapping or tied together, that are simultaneously strange, irregular and unexplained and that he has to first apprehend and then present. For example, interviewing informants, observing rituals, can often seem strange, deduce kinship terms, draw property lines, and even write your diary. Doing ethnography is like trying to read a strange manuscript, full of eclipses, inconsistencies that we think are as such, suspicious amendments and biased comments, written not with conventional sound signals, but transient examples of modeled behavior(GEERTZ, 2008: 7).

For Geertz, the place of culture is in the mind and heart of man, but it is a public identity because its meaning is public; it is a document that results in action; it is alive and active all the time (GEERTZ, 2008: $8-9)$. The author criticizes the Westerners' view of non-Westerners. He understands that, "instead of trying to fit the experience of other cultures within the Western framework, to understand other people's conceptions it is necessary that we leave aside our conception, and let us seek to see the experiences of others in relation to their own conception of the self"(GEERTZ, 2008: 91).

Culture, for Geertz, is socially transmitted. From birth, the person learns rules of conduct, forms of expression and language adopted in the context in which he lives. Therefore, the human being is, thus, shaped by society and apprehends its culture from birth (JUNQUEIRA, 2008: 19).

In this perspective, Geertz reinforces the idea that the goal of anthropology is to expand the universe of human discourse. However, this is not its only goal, education, entertainment, practical advice, moral advancement and the discovery of the natural order in human behavior are others, and anthropology is not the only discipline to pursue them.

However, this is an objective to which the concept of semiotic culture is well suited. As intertwined systems of interpretable signs, culture is not a power, something to which social events can be causally attributed, behaviors, institutions or processes. It is a context, something within which they can be described in an intelligible way, that is, described with density (GEERTZ, 2008: 10). The term culture is polysemic. The work with the land, the act of cultivating, can be called culture. Culture also serves to designate instruction, intellectual development. In anthropology, it was agreed that the standards of behavior, institutions, material and spiritual values of a people are its culture (JUNQUEIRA, 2008: 14-15).

Therefore, in view of what we have just presented, we clearly see that the people under study, it is a people that has undergone westernization, that is, a process of usurpation based on colonial domination, the result of what Junqueira called social immaturity, that instead of conviviality and respect, cultural exchanges in its various aspects, it opted for the domination, exclusion and extermination of non-white peoples in the most diverse parts of the globe. Thus, people in Africa under European domination, in particular Portuguese, were forced to renounce their cultural identity and as a result of their resistance they were slaughtered for being and thinking differently from the western.

From this, we ask ourselves what aspects of the culture of the Nyungwe people did colonialism fight and fail to eliminate? Is there anything left of this culture? In our research, we understand that yes, and of what remains the worldview stands out, that is, the idea that the people have about the world and the human being; the way the people relate to all realities in the horizontal and vertical dimension (ABREU, 2006: 20-21) the way people relate to their ancestors in the face of health, and in the face of disease and death and finally analyze the singing, the dancing, the masks and the metaphors are real vehicles that carry the historical memory of that time (MAIA, 2011: 44). 
We are going to present only a corner full of metaphors that clearly illustrates the resistance of Zambezi people against the colonial situation. This song is sung to this day in playful moments.

\section{The use of metaphor between the dema and nyungwe}

Between the Dema and Nyungwe we find several metaphors produced according to a specific social time . we highlight some here.

\section{Proverbial resistance metaphors}

The Nyungwe proverb says: "azungu ndi madzi, ife ndife ncenga", that is, Europeans are the water that passes (KI-ZERBO, 2009: 33), we are the sand that remains" (MARTINS, 2001: 19). This metaphorized proverb carries a very strong moral of tradition. It warns about the care in relations and in any pacts or alliances with alien powers. It is implicit in the proverb that taking care of endogenous social relations is fundamental, because the one who comes, one day he will return to his homeland. Therefore, it is necessary to avoid, at all costs, backyards of enmity.

In the contact with otherness, throughout history, the Dema and Nyungwe society has developed the metaphor as a distinctive theoretical operator alerting new and future generations to remain critical about the paths of change and social transformation (VIVEIROS DE CASTRO, 2011), in order not to lose their cultural values (APPIAH, 1997: 119) in contact with other peoples from other non-African cultural backgrounds.

It is in this way that, on the border between what comes and goes and between what comes and stays, water and sand, in the historical memory of the Dema and Nyungwe people metaphorically in relations with colonial power, represents indigenous and alius.

The metaphor also appears in multiple endogenous social cases linked to marital exchanges, good manners and good examples in the family court and in funeral rituals. In short, the metaphor runs through the entire life cycle between Dema and Nyungwe, from birth to death.

The metaphor of resistance is not only present in the proverbial literature, but also in the love songs, where loving verses and resistance verses are mixed.

In the song we are going to show, the soloist begins by asking: - do we choose? and the choir says: - yes. The soloist asks again: - what are we going to choose? The choir responds: - let's choose the virgins. The child grew up. - what are we going to choose?

Let's choose the virgins. In the midst of moods, the soloist changes his verse: - You whites !!!, and the choir responds: ye ye ye! - White you, go back to your land. !!!!

We warn that it is difficult to find the composers of such songs, they pass from generation to generation and people are learning orally. So the love song, sung on fun nights, after hard labor during the day, the people could express their feelings of resistance in the music, in a subtle and soft way to hinder the understanding of the alius, that is, from the masters of the colonial situation.

\section{Metaphors of resistance in bridal singing \\ Tisankhule, Éa éTisankhule, Sankhule madende. Ref. (2x;4x ou $5 x)$}

\section{1) Wakula mwana/ Ea é}

Wakula mwana/ Sankhula madende.

\section{2) Azungumwe,/ Ea é}

Azungumwe/ Sankhula madende.

3) Ndokoni kwanu,/Ea é

Ndokoni kwanu/ Sankhula madende.

Therefore, the colonial situation tried in every way to combat nonWestern cultures in different corners of the world during the process of European expansion, however, there were resistances in different forms specific to each people and each culture. For the peoples of the Zambezi Valley, metaphors were used as a means of resistance, without, however, drawing the attention of the Lords who own the colonial situation. Resistance itself became an art, where, behind dance and singing, the voice and the cry of resistance resounded and echoed with poetic subtlety. In this sense, each man in his own culture finds cultural means to face threats to his identity and integrity. Culture conditions the view of the world and of man (LARAIA, 2008: 67). "To truly serve man, each authentic culture must be open to transcendence and, ultimately, to God," says Benedict XVI (Benedict XVI, 2010: 198, n $\circ 109)$.

\section{Final consideration}

The entire colonial situation was marked by a relationship of superiority that was reflected in the appropriation of territories, domination, and the implantation of a Western cultural system that made tabula raza all non-Western peoples and cultures. As a consequence, the African peoples of the Zambezi Valley, used song, dance, masks, proverbs and metaphors as vehicles of subtle resistance to the colonial situation. In this sense, we can affirm that intercultural relations during the colonial situation were guided by an authentic waste of the alteritarian experience.

\section{Acknowledgments}

None.

\section{Conflicts of interest}

The author declares that there is no conflict of interest.

\section{Funding}

None.

\section{References}

1. Benedict xvi. Post-Synodal Apostolic Exhortation, Verbum Domini. No. 109. São Paulo: Paulinas; 2010.

2. José Luis C. Editoria UNESP, Identity, Colonialism and Liberation. São Paulo: Mozambique; 2009.

3. Julius C. Latin Program: Introduction to the Latin language. Vol(1) 18th Ed. Ver. and current. Sao Paulo: Editora Salesiana, 2002.

4. Gaudium et spes. Pastoral Constitution of the Second Vatican Council On the Church in Today's World. No. (53)

5. Clifford G. The Interpretation of Cultures. LTC-Technical and Scientific Books Editora S.A.Rio de Janerio; 2008.

6. Porto A. A frontamento Editions, Hastings: wiritamu; 1974.

7. Hall S. Cultural identity in postmodernity. 6th Ed. Rio de Janeiro: DP\&A, 2001.

8. Carmen. Indigenous anthropology: a new introduction. São Paulo: junqueria; 2008. 
9. Joseph K. When to Africa? Interview with René Holenstein. pallas, Rio de Janeiro: 2009.

10. Roque de Barros, Laraia. Culture: An anthropological concept. Rio de Janeiro: Jorge Zahar ed., 2008.

11. Levi-Strauss, Claude. Race and History. Editorial Presença, lisbon;2000.

12. Emmanuel L. From God the idea comes. Petrópolis, 2002.

13. Emmanuel L. From Existence to Existing. Papirus, Campinas: São Paulo; 1998.

14. Manuel dos Anjos, Martins. Cuma Cathu Natisunge: Riddles, Proverbs, Tales of the Nyungwes (Tete - Mozambique). Beira, 2001.

15. Manuel dos Anjos M. Elements of the Nyungwe language, grammar and Nyungwe-Portuguese-Nyungwe Dictionary. Editorial Além-Mar, Calçada Eng. Miguel Pais, 9-1200, 1st Edition Lisbon:1991.

16. Manuel dos Anjos M. Elements of the Nyungwe language, grammar and Nyungwe-Portuguese-Nyungwe Dictionary. Lisbon: Editorial Além-Mar, Calçada Eng. Miguel Pais, 9-1200, 1st Edition 1991.
17. Alessandro P. Oral History Essay. Letter and voices, São Paulo: 2010

18. Angelo-Artes e Letra, Lourenço Joaquim da Costa. The African Narrative of Oral Expression, Institute of Culture and Portuguese Language, $1^{\text {st }}$ Edition, Rosario: Lisbon;1989.

19. Carmen Lucia, Salgado, Maria Teresa and Jorge. Approximation and detachment, a revisiting of the theoretical apparatus. In SECCO. Thinking Africa: Literature, Art, Culture and Education. Ministry of Culture, National Library Foundation, Rio de Janeiro: 2010.

20. Rufin, Waway Kimbanda. Dialogue between cultures and mission: anthropological-theological perspective. In Journal of Theological Culture (Pontifical Faculty of Theology of Our Lady of the Assumption). Paulinas, São Paulo. 14(56):2006.

21. Eduardo, "Transformation" in anthropology, transformation of "anthropology". Nursery de Castro: SOPRO; 2011. 